\title{
Clinical, hematological and histopathological aspects of experimental induction of laminitis in cattle through lipopolysaccharide infusion
}

\author{
Antônio Amaral Barbosa ${ }^{*}$ (D) Maria Carolina Narval de Araújo ${ }^{1}$ (D) Andressa Stein Maffi ${ }^{2}$ (D) \\ Joao Alveiro Alvarado Rincón ${ }^{1}$ Margarida Buss Raffi ${ }^{3}$ (D) Eduardo Schmitt ${ }^{4}$ (i) \\ Viviane Rohrig Rabassa ${ }^{4}$ (i) Cássio Cassal Brauner ${ }^{5}$ (i) Marcio Nunes Corrêa ${ }^{4}$ (D)
}

${ }^{1}$ Programa de Pós-graduação em Veterinária, Universidade Federal de Pelotas (UFPel), 96160-000, Pelotas, RS, Brasil. E-mail: antoniobarbosa.vet@hotmail.com. *Corresponding author.

${ }^{2}$ Programa de Pós-graduação em Zootecnia, Universidade Federal de Pelotas (UFPel), Pelotas, RS, Brasil.

${ }^{3}$ Departamento de Patologia Animal, Faculdade de Veterinária, Universidade Federal de Pelotas (UFPel), Pelotas, RS, Brasil.

${ }^{4}$ Departamento de Clínicas Veterinária, Faculdade de Veterinária, Universidade Federal de Pelotas (UFPel), Pelotas, RS, Brasil.

${ }^{5}$ Departamento de Zootecnia, Faculdade de Agronomia Eliseu Maciel, Universidade Federal de Pelotas (UFPel), Pelotas, RS, Brasil.

ABSTRACT: The purpose of this research was to confirm the changes occurring in the foot system of the heifers challenged with lipopolysaccharides (LPS), at the clinical, serum and histological levels. We studied 16 clinically healthy heifers, 14 months of age, placed in a confinement system. All the animals were provided with an accelerometer collar to establish their activity. They were categorized into two groups: the LPS group ( $n=8)$, or those which were administered two intravenous applications of $2 \mathrm{~mL}$ containing $0.5 \mu \mathrm{g} / \mathrm{kg}$ of body weight of LPS, with a 24-hour interval and the Control group $(n=8)$ which were given two infusions of $2 m L$ of saline solution in the same time interval. General clinical examination and blood collection were done at 0,4 and 8 hours post the LPS challenges and analyses of the hemograms and paroxonese-1 were performed. The animals were then slaughtered on day 4 and the laminar tissue was collected for histological analysis. The LPS group revealed a lower total leukocyte count with heart rate and greater activity. None of the animals revealed any abnormal signs symptomatic of foot pathology after histological analysis. Hence, the challenge with LPS failed to induce any clinical and histological changes in the foot tissue compatible with laminitis.

Key words: laminitis induced, hoof histology, cattle.

Aspectos clínicos, hematológicos e histopatológicos da indução experimental por lipopolissacarídeos de laminite em bovinos

RESUMO: O objetivo deste trabalho foi verificar alterações do sistema podal á nível clínico, hematológico e histológico de animais desafiados com lipopolissacarídeo (LPS). Foram utilizadas 16 novilhas de corte com 14 meses de idade, clinicamente saudáveis, em sistema de confinamento. Todos os animais continham uma coleira com acelerômetro para verificar atividade, sendo divididos em 2 grupos: LPS ( $n=8$ ), que recebeu duas aplicações de $2 \mathrm{~mL}$ contendo $0,5 \mu \mathrm{g} / \mathrm{kg}$ de peso corporal de LPS via intravenosa, com intervalo de 24 horas e Controle ( $n=8$ ) que recebeu duas aplicações de $2 \mathrm{~mL}$ de solução salina com o mesmo intervalo de tempo. Foram realizados exame clinico geral e coletas de sangue às 0 , 4 e 8 horas após os desafios com LPS para análise de hemogramas e paroxonase-1. Os animais foram abatidos aos 5 dias sendo executada a coleta de tecido laminar para análise histológica. A análise estatística foi executada com a utilização do programa NCSS(2004) através de ANOVA-medidas repetidas, considerando o efeito do tratamento do periodo e sua interação (tratamento*horas), sendo considerados significativos valores de P<0,05. O grupo LPS apresentou superior contagem total de leucócitos com maior frequência cardiaca e atividade. Nenhum animal apresentou sinal de anormalidade compatível com laminite através da análise histológica. Entretanto, o desafio com LPS foi capaz de gerar alterações a nivel clínico, constatado pelas alterações nos parâmetros de frequência cardíaca, respiratória e temperatura corporal, além de mudanças no leucograma.

Palavras-chave: laminite induzida, histologia podal, bovino.

\section{INTRODUCTION}

Locomotor disorders represent the primary reason for the negative impacts on animal stardom today, causing persistent pain and discomfort (BICALHO et al., 2007; TAVARES et. al., 2019).Economic losses induced by lameness are estimated to be second only to the losses produced by mastitis and reproductive tract diseases (GREENOUGH, 2007), which exert a direct negative effect on the milk production. In 
fact, lameness is responsible for more than $20 \%$ loss through lactation as it raises the risk of the occurrence of mastitis in the herd (FERREIRA, 2003), apart from compromising their reproductive performance.

Among the diseases affecting the locomotive system, the most prominent is laminitis, which represents $80 \%$ of the instances of foot diseases (FERREIRA, 2003). This disease, otherwise termed diffuse aseptic pododermatitis or choriosis, is specified to mean the inflammation of the hoof wall laminae in bovines and equines. The physiopathology of this disease is distinguished by the epidermal laminae of the hoof showing degeneration, necrosis and inflammation (NICOLETTI, 2004). It is as yet unclear as to precisely which factor determines the appearance of the laminar tissue inflammation, as well as the degree of this inflammation in the other hoof structures in cattle (THOEFNER et al., 2005). Although, it is regarded as a disease of multifactorial etiology, where the relationship between the environment management and body condition can be considered as among the factors that contributed to the development of this disease, nutrition management is still viewed to play a crucial role in the onset of foot diseases. In this context, animals placed on a high carbohydrate diet can produce ruminal acidosis, which in turn exerts a direct effect on the occurrence of laminitis (NOCEK, 1997; ENEMARK, 2008; NAGARAJA \& TITGEMEYER, 2007).

A few of the theories regarding the pathophysiology of laminitis (FERREIRA, 2003; KOFLER 2017), include the ischemic, toxicenzymatic, systemic inflammatory response syndrome (SIRS) and insulin resistance. However, the most acceptable pathogeny for the scientific community is the intake of carbohydrate-rich grains, containing Gram-positive bacteria (Streptococcus bovis and Lactobacillus sp.) which multiply in the rumen and produce lactic acid. This lactic acid, in turn, activates the metalloproteinase enzymes and lowers the intraluminal $\mathrm{pH}$ (acidosis), destroying the Gram-negative bacteria and releasing the endotoxins present in their structures, viz., the lipopolysaccharides (LPS) (BLOWEY et al., 2008). Simultaneously, inflammatory responses (edema and hemorrhage) are observed to take place in the mucosa, raising the vascular permeability. Consequently, these toxins, mainly the LPS, are absorbed into the bloodstream. These now trigger the endotoxemic disorders that will initiate the commencement of the aseptic pododermatitis process (BAILEY et al., 2004).

The connection between experimentallyinduced acidosis and the development of laminitis has been verified both in horses and cattle, either via oligofructose overload or through excessive concentrate (NILSSON, 1963; THOEFNER et al., 2005). However, the action mechanism involving LPS and the inflammation with the incidence of laminitis are still under speculation, and the scientific community is yet to arrive at a consensus on how ruminal acidosis could activate a backlash at the level of the locomotor system.

The LPS is a cell wall constituent of the Gram-negative bacteria, composed of an O-specific side chain, a polysaccharide nucleus and lipid A (ANDERSEN, 2003). Either the proliferation or destruction of the Gram-negative bacteria will liberate large quantities of free endotoxins, which can be absorbed in the event of ruminal wall or intestinal tract damage (DONG et al., 2011). Interaction between the endotoxins and immune system triggers a cascade of events resulting in serious outcomes, particularly in the microcirculation (SMITH, 2005). Endotoxins influence the mononuclear phagocytes to release pro-inflammatory cytokines such as interleukin 1, interleukin 6 and the tumor necrosis factor alpha. These mediators once released, stimulate the hepatic production of the acute phase proteins, namely the serum amyloid A, haptoglobin, and a protein binding lipopolysaccharide Paraoxonase-1 (PON1) fibrinogen (DANSCHER et al., 2010; DONG et al., 2011). The part played by the endotoxins in laminitis is believed to be caused by their hemodynamic effects on the chorion, as an endothelial lesion, a disordered clot formation or their action as a collagen-degrading enzyme activator (GREENOUGH, 2007).

In light of the facts mentioned, it is evident that LPS plays a pivotal part in the metabolic interrelationships that commence in acidosis and culminate in laminitis. However, the intensity or isolation of the influence exerted by this component continues to remain poorly investigated. Our hypothesis is that those animals experiencing high levels of exogenous LPS will display clinical, hematological and histological changes, compatible with laminitis. The goal of this study,; therefore, was to ascertain the changes in the foot system at the clinical, serum and histological levels of the LPSchallenged animals.

\section{MATERIALS AND METHODS}

In this study we used 16 clinically healthy, European heifers (Hereford / Angus), about 14 months of age, weighing around $330 \mathrm{~kg}$, which were managed in an intensive system with free access to 
water. The animals were maintained in a covered shed divided by pens, having lateral openings to house 8 animals / pen.

In the course of the study period, the animals were put on a diet which included corn silage, soybean meal and corn grain, consisting of $60 \%$ dry matter, $65 \%$ NDT, $26.8 \%$ NDF and $12.6 \%$ protein gross, besides free access to water. The diet selected included $60 \%$ roughage and $40 \%$ concentrateto circumvent acidosis and alterations in the results (NRC, 1996).

First, the heifers were randomly separated into two categories: the LPS group $(n=8)$, which were given two intravenous administrations of $2 \mathrm{~mL}$ of saline $(0.9 \% \mathrm{NaCl})$ containing $0.5 \mu \mathrm{g} / \mathrm{kg}$ body weight of LPS E. coli (O111: B4, SIGMA, St. Louis, MO, USA), 24 hours apart; and a control group ( $\mathrm{n}=$ 8 ) that was given two applications of $2 \mathrm{~mL}$ of saline $(0.9 \% \mathrm{NaCl})$ in the same time interval (Figure 1).

\section{Control of food intake and animal behavior}

When the experiment (D1) commenced, all the animals were provided with a collar having an accelerometer (Chip Inside ${ }^{\circledR}$ ), to evaluate their behavior. Data during the leisure time, activity and rumination of each animal were collected for 13 hours. Besides, the diet given to the animals and the remnants were weighed during the morning and afternoon.

\section{Clinical evaluation}

To accomplish the clinical examination, the animals were contained in a piece and the rectal temperature, heart rate (HR) and respiratory rate
(RF) were recorded. On the days that the LPS was administered (D1 and D2) the animals were assessed for FR and HR prior to the treatment and 4 and 8 hours post the challenge. On the other days, the animals were assessed once a day, at 24-hour intervals.

The temperature of the animals was recorded every 30 minutes right through the duration of the experiment, with an intravaginal data logger thermometer (iButton, Thermochron, Whitewater, USA).

Every day the animals were subjected to an orthopedic evaluation employing the locomotion score (WINCKLER \&WILLEN, 2001) and specific clinical examination to confirm the digital pulse and likely laminitis-related injuries.

\section{Blood collections}

The Vacutainer system (BD Diagnostics, São Paulo, Brazil) was used to draw the blood samples from the coccygeal arteriovenous complex. Concomitant collections were done with clinical estimations in tubes without adding any anticoagulant to evaluate the PON1 levels, and in tubes containing sodium fluoride for the hematological analysis. Post collection, the tubes having no anticoagulant were centrifuged and the serum was transferred to Eppendorf bottles and stored at $-20{ }^{\circ} \mathrm{C}$ for analysis at a later date.

The serum PON1 activity was determined by adopting a protocol described earlier (BROWNE et al., 2007). Hematological analysis was done with automatic equipment utilizing whole blood drawn with sodium fluoride via the impedance

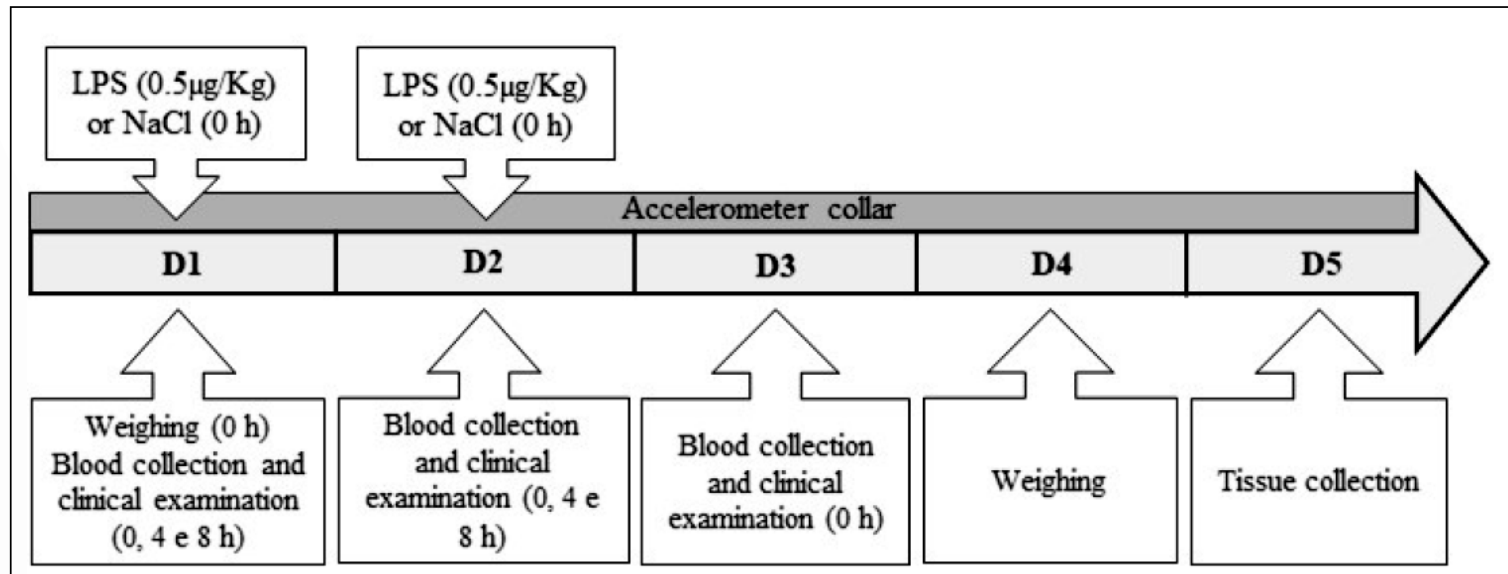

Figure 1 - Experimental design. 
technique to estimate the red blood phase. Flow cytometry was used to assess the white phase, with the BC-2800 automatic counter (Mindray ${ }^{\circledR}$, China). Besides, the leukocyte differential was determined using the Panotype-stained (Laborclin, Brazil) blood smears and the readings were taken on the Nikon Eclipse E200 microscope (Nikon, Japan) with a 1000x magnification. To analyze the fibrinogen, we used the heat precipitation method (MILLAR et al., 1971).

\section{Tissue collection and histological evaluation}

On day 5 of the experiment, the animals were slaughterin the refrigerator in the place where the animals were housed and the epidermal blades were collected. After the digits were opened the laminar tissue was collected from the dorsal portion of the nails of all the digits (Figure 2). Fixation was done using $10 \%$ formalin solution for histological processing at a later point in time (LUNA, 1968).

Next, the laminar tissue samples were processed adopting the traditional histological processing method, with subsequent inclusion into paraffin blocks, based on the routine technique. Then, we mounted the $5 \mu \mathrm{m}$ thick histological sections. Histological assessments of the laminar tissue were done according to the method described by THOEFNER et al., (2005). This research revealed the histopathological characteristics that could represent the injuries likely produced through experimentally induced laminitis. According to MENDES et al., (2013) this included the characterized scores as a quantification method. Using the H\&E-stained slides, the morphology of the epidermal cells, presence and intensity of the inflammatory infiltrate, hemorrhage, congestion and tapering and stretching of the epidermal slides were assessed.

\section{Statistical analysis}

Data analyses were done with the NCSS program (2004) using ANOVA - repeated measures, in light of the influence exerted by the treatment (Control and LPS), the duration (in hours) of data collection and their interaction (treatment ${ }^{*}$ hours). P values $<0.05$ were accepted as significant. Results are given as mean \pm standard error of the mean.

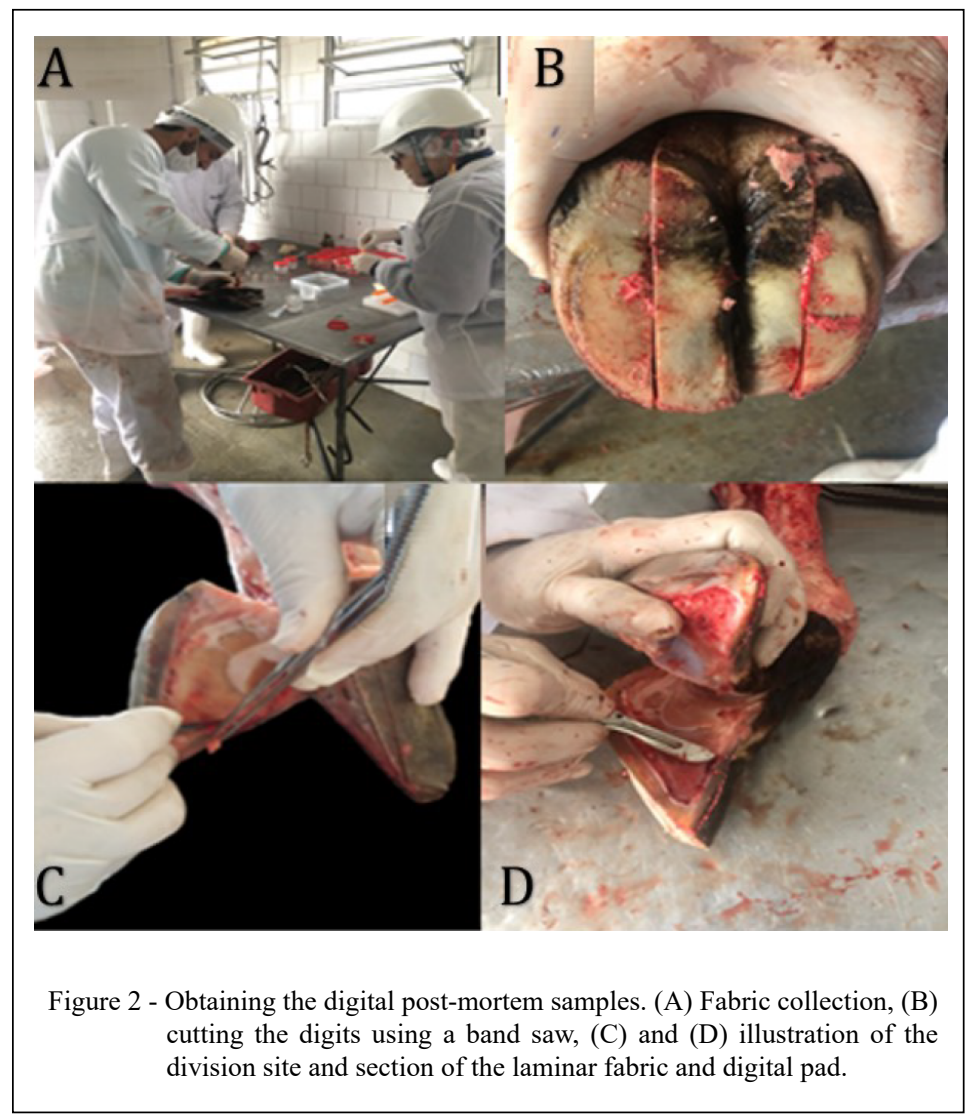

Ciência Rural, v.50, n.8, 2020. 


\section{RESULTS}

To clarify the likely mechanisms involved in the reactions between ruminal acidosis and laminitis, intravenous LPS administration was used as an instrument to experimentally replicate the endotoxemia that occurs due to the ruminal acidosis process.

The LPS group revealed heightened HR during the entire experimental duration in comparison to the Control group $(91.52 \pm 5.08$ vs $104.5 \pm 4.48 \mathrm{btm}$ / min; $\mathrm{p}=0.04$; Figure 3 ). Rectal temperature revealed an interaction between the treatment and collection hours $(\mathrm{p}=0.0003)$; in fact, the animals subjected to the LPS challenge displayed a temperature rise 4 hours after the first administration $(39.93 \pm 0.18$ vs $\left.39.10 \pm 0.08{ }^{\circ} \mathrm{C} ; \mathrm{p}=0.02\right)$ and then after the second challenge $\left(40.44 \pm 0.35\right.$ vs $39.34 \pm 0.11{ }^{\circ} \mathrm{C} ; \mathrm{p}=$ 0.004; Figure 4), indicating the systemic response. Besides, 40 hours post the first challenge, the LPS group registered a decrease in temperature more than the control group $\operatorname{did}\left(38.63 \pm 0.14\right.$ vs $39.41 \pm 0.28^{\circ}$ $\mathrm{C} ; \mathrm{p}=0.046$ ). However, the respiratory rate during the period of assessment remained unaffected by the challenge (LPS: $47.44 \pm 5.32 \mathrm{mr} / \mathrm{min}$; Control: $47.98 \pm 5.14 \mathrm{mr} / \mathrm{min} ; \mathrm{p}=0.85)$.

The total leukocyte count revealed an interplay between the LPS challenge and time of collection $(p<0.0001)$. The challenged animals (LPS) showed a lower total leukocyte count than did the control group (LPS: $12884.64 \pm 1129.17$ vs Control: $17029.54 \pm 1129.17 ; \mathrm{p}=0.02$ ). Besides, the LPS group showed a leukometric drop 4 hours after the first challenge ( $p=0.00005$; Figure 5).

Results mentioned earlier encouraged the hypothesis that the LPS will induce a systemic response, confirming that the challenge based on the clinical and leukocyte changes was successful. The laminar tissue patterns in both groups showed no alteration; in fact, there was no change in the physiological pattern of these animals either (Figure 6).

With respect to the orthopedic examination, none of the animals showed either clinical changes or the occurrence of a laminitis-compatible lesion. During the 13-hour evaluation period, the rumination time (SPL: $19.66 \pm 1.25 \mathrm{~min} / \mathrm{h}$; Control: $18.11 \pm 1.46 \mathrm{~min} / \mathrm{h}$ ) and leisure (LPS: $35.73 \pm$ $1.56 \mathrm{~min} / \mathrm{h}$; Control: $33.66 \pm 2.02 \mathrm{~min} / \mathrm{h}$ ) were similar between the groups $(\mathrm{p}=0.07$ and $\mathrm{p}=0$, 46; respectively; Figure 7). However, the activity was lower in the LPS-challenged animals $(4.62 \pm 1.02$ $\mathrm{min} / \mathrm{h})$ than in that of the Control $(8.23 \pm 1.36 \mathrm{~min} /$ $h ; p=0.01$; Figure 7).

The PON1 activity in both the LPS group $(84.98 \pm 3.93 \mathrm{U} / \mathrm{mL})$ and Control group was similar $(88.49 \pm 1.26 \mathrm{U} / \mathrm{mL} ; \mathrm{p}=0.52)$, indicating that the LPS challenge had no effect (Figure 8).

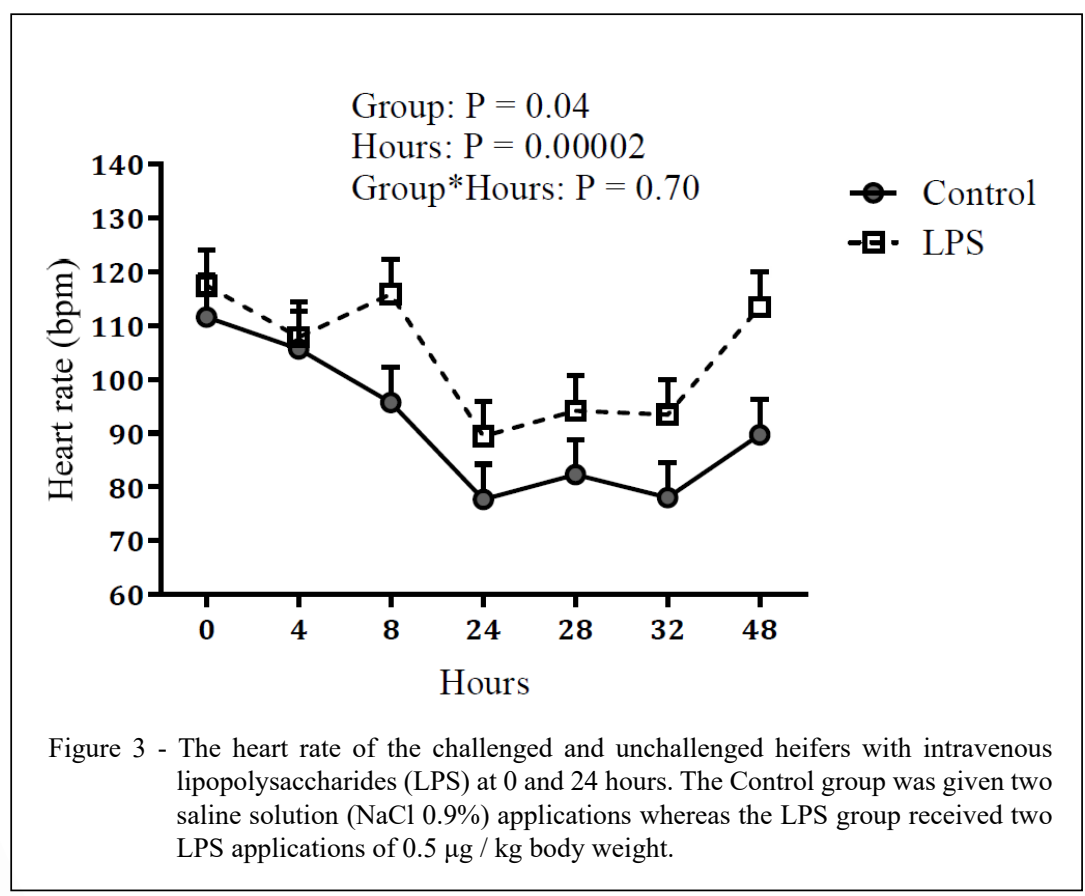

Ciência Rural, v.50, n.8, 2020. 


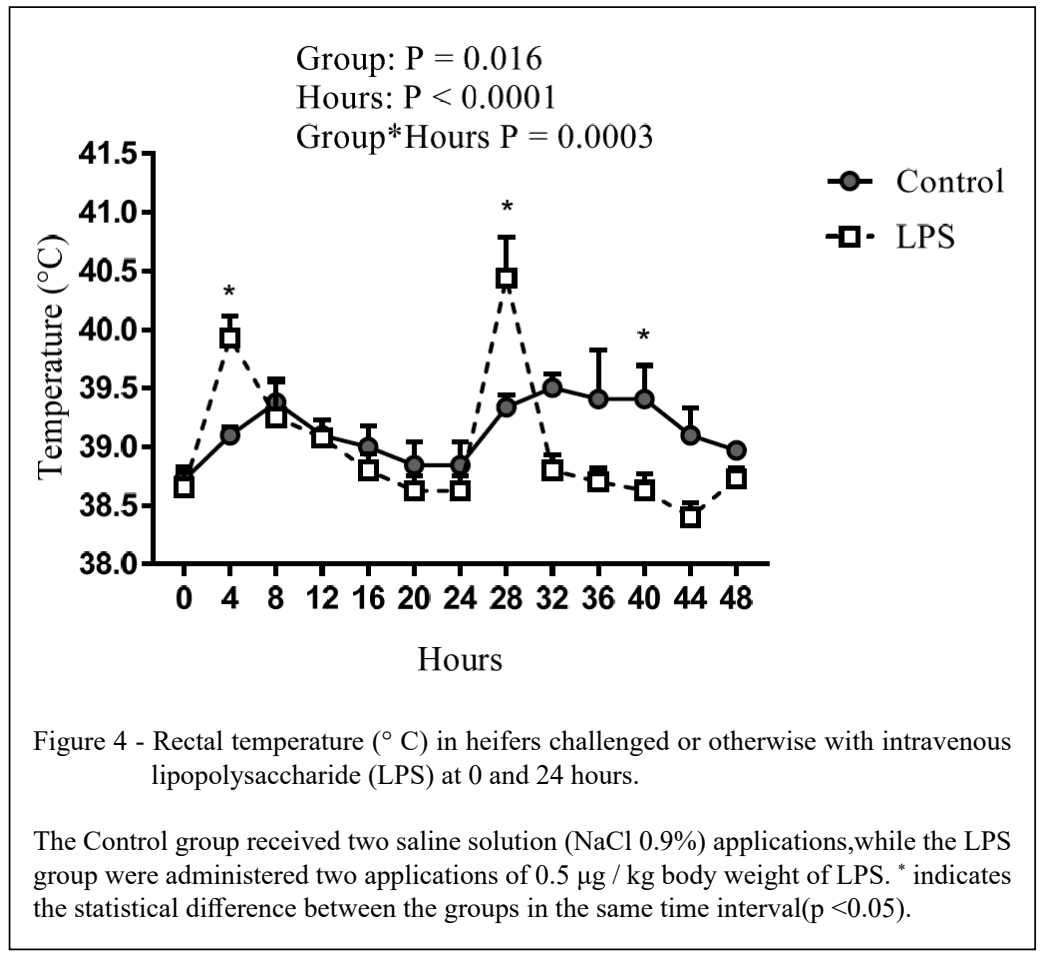

\section{DISCUSSION}

On estimating the HR, the LPS group evidently revealed an escalated HR throughout the entire study period when compared to the Control group (Figure 3), showing physiological values ranging from 60 and $80 \mathrm{bpm}$ (FEITOSA, 2008).

This effect may have been induced by the capacity of the LPS to stimulate the nitric oxide production (CERQUEIRA \& YOSHIDA, 2002) which, in turn, encourages vasodilation and the release of the cytokines like interleukin-1 (IL-1) and tumor necrosis factor alpha (TNF- $\alpha$ ). These cytokines trigger platelet degranulation and leukocyte adhesion to the endothelium (BEYAERT \& FIERS, 1998), inducing hypotension and raising the vascular permeability which increase the blood viscosity and concentration, as well as lowering the degree of tissue perfusion (GERROS et al., 1995). To compensate for this, there is a responsive activation of the sympathetic nervous system, release of the renin-angiotensin-aldosterone and antidiuretic hormones, as well as a decrease in the hydrostatic pressure within the blood capillaries. These mechanisms thus cause a rise in the fluid retention and peripheral vasoconstriction, producing heightened circulatory volume, cardiac output and tissue perfusion (BISTNER et al., 2002), thus accounting for the increased HR.

Thus, because of the major hemodynamic disorders induced by severe leukocyte mobilization, the foot tissue was expected to experience circulatory deficit leading to hypoxia and culminating in cell death. It was also expected that this event together with the greater difficulty posed by the immune cells arriving at the site, would induce extreme consequences to the foot tissue and laminitis; however, this scenario was not evident in the current study.

On analysis of the RF, the groups revealed no significant difference, but rather showed a progressive escalation over time, with the physiological values hovering in the 10-30 mrpm range (FEITOSA, 2008), with day 3 indicating a difference from days 1 and 2, at 0 and 4 hours. In the light of the knowledge that LPS induces blood flow distribution changes, an imbalance was expected between tissue demand and oxygen supply, precipitating a situation where the tissue experiences high flow; although, still inadequate to meet the metabolic requirements (SIQUEIRA \& SCHMIDT, 2003).

Although, no difference was evident between the Control group and LPS group, both showed RF values which exceeded the physiological level. It is probable that this tachypnea can be 


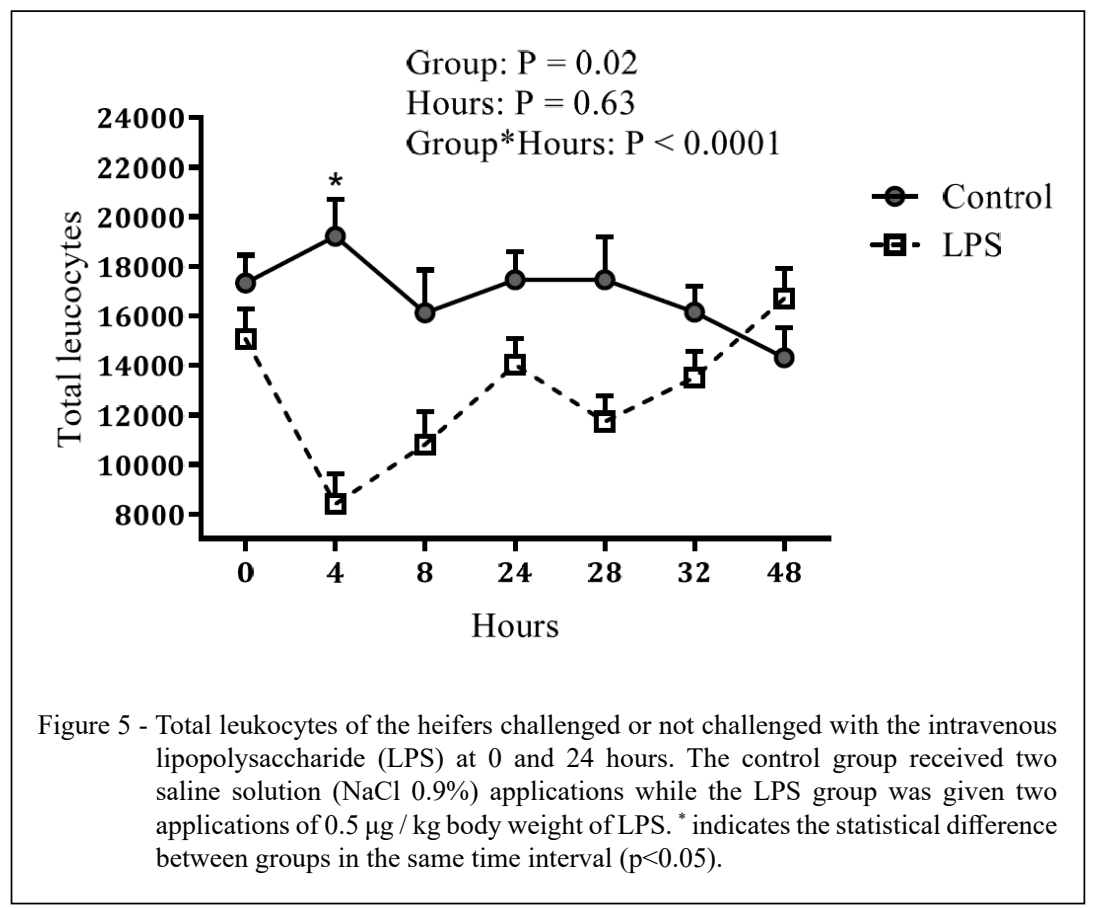

accounted as a result of the daily management, because being meat animals, they were unused to such manipulation, which thus acted as a stressor for these heifers. According to Breazile (1987) animals during stress periods produce glucocorticoids, which exert an anti-inflammatory and immunosuppressive actions, besides releasing catecholamines that induce increased blood circulation, an effect that corresponds to the events that occur when endotoxin is present, causing alterations in the blood and respiratory flow.

Just after the challenge in the LPS group (Figure 4), a temperature rise $(p<0.05)$ was evident in 4 hours, noting that the physiological values hovered between $38.4{ }^{\circ} \mathrm{C}$ to $39.2{ }^{\circ} \mathrm{C}$ (FEITOSA, 2008). In fact,

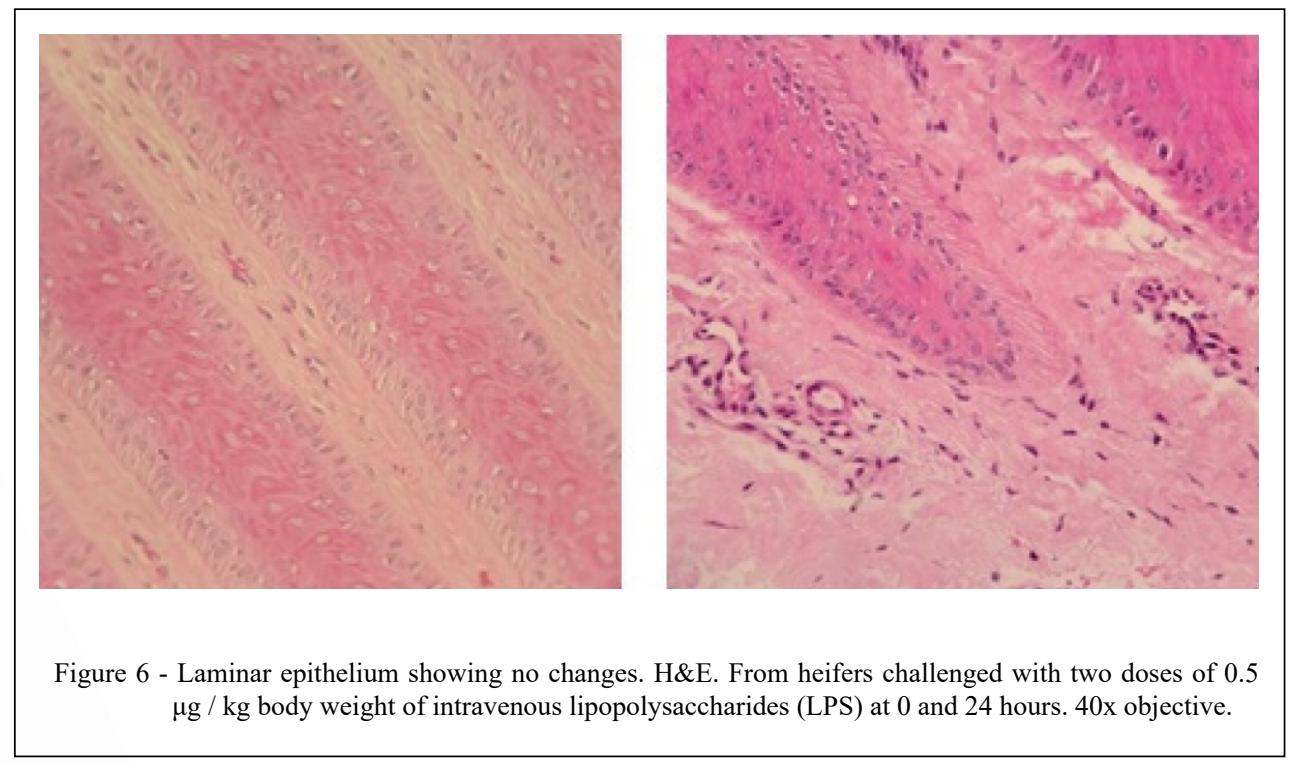

Ciência Rural, v.50, n.8, 2020. 
QUINN et al., (2005) reported that low LPS levels induce fever by producing the endogenous pyrogens, namely interleukin-1 and leukocyte tumor necrosis factor. These pro-inflammatory cytokines stimulate the production of the prostaglandins which trigger the hypothalamic thermoregulatory center thus altering the thermoregulation threshold to an increased temperature, thus encouraging the body temperature mechanisms to escalate above homeostatic levels (CRUZ-MACHADO, 2018). It was ANDERSEN (2003) who reported that the initial hyperthermia response has a latency time of about one hour and that, if a second peak occurs, this will happen in roughly four hours post the LPS administration.

Hence the clinical (FC, FR, Temp.) as well as the hematological findings mentioned above, prove that the LPS simulation effectively mimicked systemic inflammation. The total leukocyte count (in cells per $\mathrm{mm} 3$ ) of the challenged animals (LPS) was lower than that of the Control group (LPS:
$12884.64 \pm 1129.17$; Control: $17029.54 \pm 1129.17$; $\mathrm{p}=0.02$ ); although, both exceeded the physiological limit. Besides, on evaluating the proportion of the total leukocytes throughout the hours after the LPS administrations (Figure 5), a drop in the leukometric concentration was noted at hour four $(p=0.00005)$ in the LPS challenged heifers.

On analysis of the influence exerted by the LPS on the leukocyte subgroups, DIEZ-FRAILE et al., (2003) determined that the decreased serum in the polymorphonucleated cells in dairy cows is caused by the alterations in the adhesion molecules ( $\mathrm{L}$ selectin and $\beta 2$ - integrins) (PERIASAMY et al., 2018). More specifically, they noted evidence of apoptosis of the bovine neutrophils from three to six hours after the LPS was administered, resulting from mitochondrial dysfunction. In their research, PEÑAILILLO et al., (2016) the rabbits which were also infused intravenously revealed a decline in the lymphocyte number at the fourth hour caused by the rapid

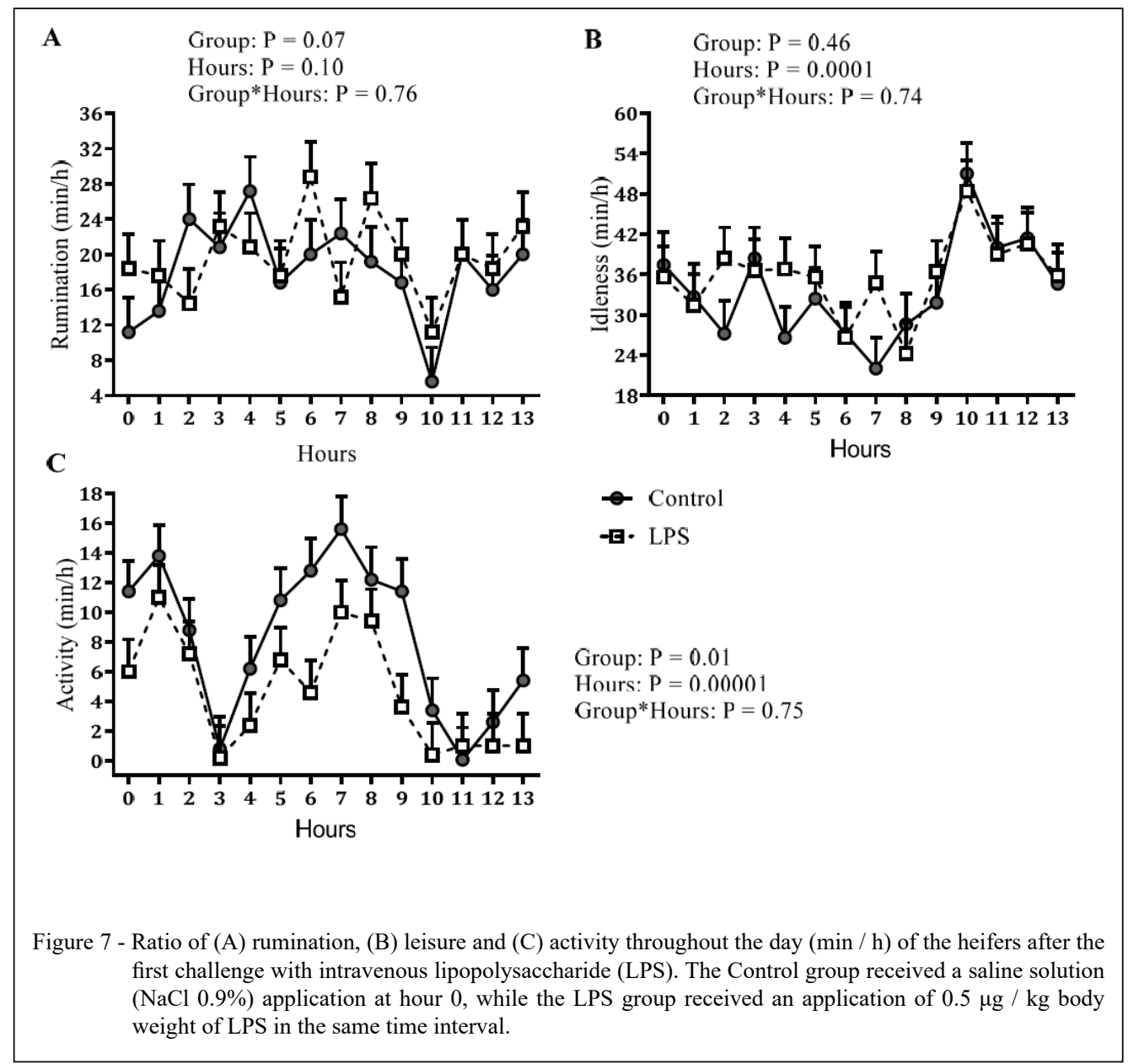

Ciência Rural, v.50, n.8, 2020. 
sequestration of these cells under the influence of the invasion. The present study revealed a similar pattern, where the reduced levels of the total leukocytes was much higher after the first LPS application, evidently indicating a response intrinsic to the LPS infusion, with a gradual resumption to the initial levels, but only balancing out again 48 hours post the challenge. This evidently revealed the immunosuppressive potential of the LPS (even if it is artificially / induced) in the animal. Thus, we arrived at the assumption that the total leukocyte count is more highly impacted in situations of infections having greater acuteness and / or extend for a prolonged length of time.

A thorough understanding of the histological features of the dermis-epidermis junction of the bovine hoof is fundamental to a clear comprehension of the physiology and biomechanics involved. In turn, the distinctive alterations in the tissue that occur during laminitis deepen our understanding of the pathophysiology of this condition (MENDES et al., 2013). None of the animals in the current study displayed any abnormalities compatible with any type of pathology through histological analysis (Figure 6).

With respect to the histological changes connected to laminitis in horses, detailed studies on the hoof have enabled researchers to more clearly comprehend this disease in the species (FALEIROS et al., 2009; FALEIROS et al., 2011; VISSER \& POLLITT, 2011); however, research of this nature in cattle continue to be scarce, which is recognized as a limiting factor in advancing the understanding of this disease.

Reports in the scientific literature deal with the histopathological changes occurring in the hoof of laminitis-affected cattle, acquired naturally (NILSSON, 1963) or induced artificially (NILSSON, 1963; THOEFNER et al., 2005; DANSCHER et al., 2010). The histopathological findings are normally associated with inflammation and morphological changes in the epidermal cells and basement membrane (NILSSON, 1963; THOEFNER et al., 2005; DANSCHER et al., 2010; MENDES et al., 2013). However, in one study on animals without laminitis, a high degree of collagen expression was noted in the dermal laminae as well as a deviation in the keratinized axis of the epidermal laminae, which were identified as a function of the peri-partum period (TARLTON et al., 2002). Thus, it can be assumed that the presence of the tissue structure changes in the hoof are linked neither to inflammation, nor to the modification of epidermal cells and the basement membrane, which may be related to laminitis.

Metabolic events which involve laminitiscompatible foot alterations arising from ruminal acidosis are attributed the administration of the

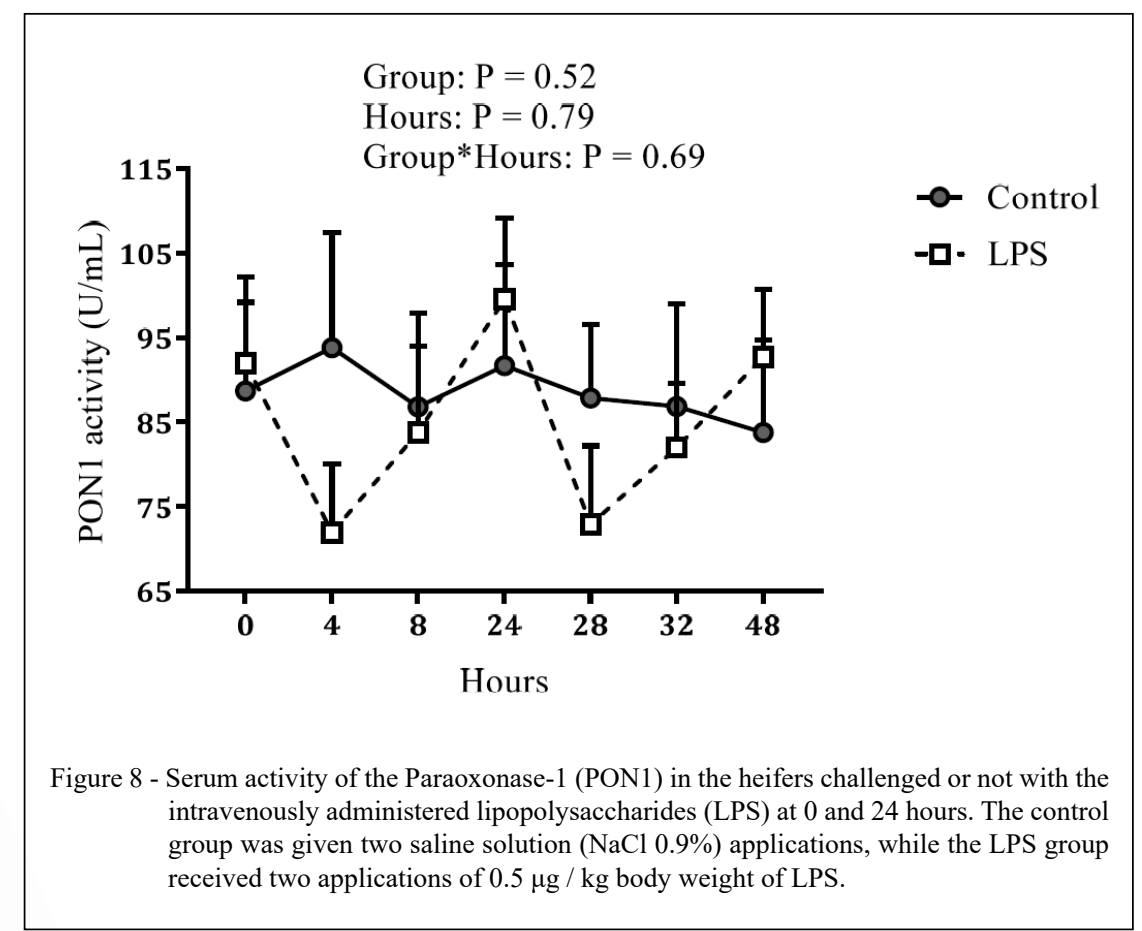

Ciência Rural, v.50, n.8, 2020. 
LPS released by the death of the ruminal bacteria, causing endotoxemia. The significant systemic effects of this event culminate in sequelae at the level of the metabolism of the foot, particularly limited to the epidermal laminae and basement membrane (TARLTON et al., 2002; FALEIROS et al., 2009). However, from the present study, such results cannot be proven because the high concentrations of the circulating LPS could not induce any negative impacts on the foot system.

Thus, one can speculate that the exposure to LPS, despite its efficacy, may not have been present in the circulation for a sufficiently long time period for the animal to exhibit the changes already reported in other studies (NILSSON, 1963; THOEFNER et al., 2005; DANSCHER et al., 2010; MENDES et al., 2013). However; although, it is true that ruminal acidosis is proven to be related to laminitis (TAVARES et al., 2019), the LPS may not halt the inflammatory potential at the foot level to kick-start the laminitis process.

Although, the two groups showed no difference in terms of rumination and idleness, on analysis of the animal behavior, it was possible to detect decreased activity in the LPS group. Until that point in time, this decrease had been thought to be the factor that would to induce the LPS group to display the distinctive symptoms of inflammation that would ultimately culminate in the prostration reactions and decreased activity.

In cattle, PON1 has been defined specifically as a negative PFA, which lowers its circulating levels when cytokines are released during any inflammation (BIONAZ et al., 2007). Therefore, the positive response to inflammatory processes and the recovery of sick animals is always connected to PON1 levels being restored to normalafter the stress period (BOSSAERT et al., 2012). Although, the LPS administered induced a systemic response, the doses infused in this study failed to influence the serum PON1 activity during the investigation, when compared to the control group. This finding did not concur with the reports of Campos et al., (2017) who observed a drop in the serum PON1 activity caused by a single challenge dose of LPS $(2.5 \mu \mathrm{g} / \mathrm{kg}$ body weight $)$. This was likely because prior to the first challenge with LPS $(-24$ hours) the Control group already possessed a lower level of PON1 activity than did the LPS group. Some factors, such as age and health status of the animals may also interfere with the serum PON1 activity in cattle (FOLNOZIC et al., 2015).

Therefore, the two LPSchallenges in the dose used and period investigated failed to trigger negative reflexes to the hoof, because no abnormalities were identified during the orthopedic clinical examination and digital histology. Thus, on considering the proven relationship between acidosis and lameness, it is conjectured that LPS is probably not the factor that triggers this process in the hull or that more intense periods of this circulating endotoxin are required for this event to be precipitated with negative consequences in the locomotor system. Therefore, further studies are necessary to raise the degree of understanding regarding the precise relationship between ruminal acidosis and laminitis.

Besides, it is mandatory to determine whether a longer exposure period to the LPS may influence the foot metabolism, thus facilitating an enhanced understanding of the routes that induce the ruminal acidosis to trigger laminitis.

\section{CONCLUSION}

The challenge with intravenous LPS failed to induce changes in the level of the foot laminar tissue compatible with laminitis. It alsodid not reveal any signs or injuries indicative of possible unfavorable impacts on the locomotor system in these animals.

\section{ACKNOWLEDGMENTS}

This study was performed thanks to the support provided by the Conselho Nacional de Desenvolvimento Científico e Tecnológico (CNPq), the Resultados da pesquisa Universidade Federal de Pelotas (UFPel), the Fundação de Amparo à Pesquisa do Estado do Rio Grande do Sul (FAPERGS) and the Coordenação de Aperfeiçoamento de Pessoal de Nível Superior (CAPES) Financing Code 001.

\section{BIOETHICS AND BIOSSECURITY COMMITTEE APPROVAL}

All the procedures adopted in this experiment were granted approval from the Animal Ethics and Experimentation Committee of the Federal University of Pelotas, Pelotas, RS, Brazil (Protocol 9364).

\section{DECLARATION OF CONFLICT OF INTERESTS}

The authors declare no conflict of interest. The founding sponsors had no role in the design of the study; in the collection, analyses, or interpretation of data; in the writing of the manuscript, and in the decision to publish the results.

\section{AUTHORS' CONTRIBUTIONS}

All authors contributed equally for the conception and writing of the manuscript. All authors critically revised the manuscript and approved of the final version. 


\section{REFERENCES}

ANDERSEN, P. H. Bovine endotoxicosis--some aspects of relevance to production diseases. A review. Acta Veterinaria Scandinavica Supplementum, v.98, p.141-55, 2003. Available from: $<$ http:/www.ncbi.nlm.nih.gov/pubmed/15259787>. Accessed: Mar. 30, 2019. doi: 10.1186/1751-0147-44-S1-S141.

BAILEY, S. R. et al. Current research and theories on the pathogenesis of acute laminitis in the horse. Veterinary Journal, v.167, n.2, p.129-42, 2004. Available from: <http://www.ncbi.nlm.nih. gov/pubmed/14975387>. Accessed: Apr. 24, 2019. doi: 10.1016/ S1090-0233(03)00120-5.

BEYAERT, R.; W. FIERS. Handbook of Immunopharmacology. In: Cytokines. Tumor necrosis factor and lymphotoxin: Elsevier, 1998, p.335-360.

BICALHO, R. et al. Association between a visual and an automated locomotion score in lactating Holstein cows. Journal of Dairy Science, v.90, n.7, p.3294-3300, 2007. Available from: <https:// www.ncbi.nlm.nih.gov/pubmed/17582114>. Accessed: Mar. 27, 2019. doi: 10.3168/jds.2007-0076.

BIONAZ, M. et. al. Plasma paraoxonase, health, inflammatory conditions, and liver function in transition dairy cows. Journal of dairy science, v.90, n.4, p.1740-1750, 2007. Available from: $\quad<$ https://www.journalofdairyscience.org/article/S00220302(07)71660-0/fulltext>. Accessed: Mar. 24, 2020. doi: 10.3168 jds.2006-445.

BISTNER, S. I. et al. Manual de procedimentos veterinários \& tratamento emergencial. São Paulo: Roca. 2002. 934p.

BOSSAERT, P. et. al. The association between indicators of inflammation and liver variables during the transition period in highyielding dairy cows: an observational study. Veterinary journal, v.192, n.2, p.222-225, 2012. Available from: <https://orbi.uliege. be/bitstream/2268/232761/1/Inflammation.pdf $>$. Accessed: Mar. 24, 2020. doi: 10.1016/j.tvj1.2011.06.004.

BLOWEY, R. W. et al. Claudicação. In: R. W. E. Blowey. Medicina Bovina: Doenças e Criação de Bovinos. São Paulo: Roca, 2008, p.362-384.

BROWNE, R. W. et al. Accuracy and biological variation of human serum paraoxonase 1 activity and polymorphism (Q192R) by kinetic enzyme assay. Clinical Chemistry, v.53, n.2, p.310317, 2007. Available from: <https:/www.ncbi.nlm.nih.gov/ pubmed/17185369>. Accessed: Mar. 28, 2019. doi: 10.1373/ clinchem.2006.074559.

CERQUEIRA, N. F.; W. B. YOSHIDA. Nitric oxide: review. Acta Cirúrgica Brasileira, v.17, p.417-423, 2002. Available from: $<$ http://www.scielo.br/scielo.php?script=sci_arttext\&pid=S01028 6502002000600011\&lng=en\&nrm=is $>$. Accessed: Mar. 29, 2019. doi: 10.1590/S0102-86502002000600011.

WINCKLER, C; WILLEN, S. The Reliability and Repeatability of a Lameness Scoring System for Use as an Indicator of Welfare in Dairy Cattle. Acta Agriculturae Scandinavica, Section A - Animal Science, v.51, n.1, p.103-107, 2001. Available from: $<$ https://www.researchgate.net/publication/249047755_The_Reliability and Repeatability of a Lameness Scoring System for Use_as_an_Indicator_of_Welfare_in_Dairy_Cattle>. Accessed: Mar. 28,2019 . doi: $1 \overline{0.1080} / 0906 \overline{6} 400131 \overline{6} 923162$.
CRUZ-MACHADO, S. S. Lipopolissacarídeo (LPS): ativador e regulador da transcrição gênica via fator de transcrição NFKB Revista da Biologia, v.4, p.40-43, 2018. Available from: <https:// www.ib.usp.br/revista/node/11>. Accessed: Mar. 28, 2019. doi: 10.7594/revbio.

DANSCHER, A. M. et al. Biomechanics and histology of bovine claw suspensory tissue in early acute laminitis. Journal of Dairy Science, v.93, n.1, p.53-62, 2010. Available from: $<$ http://www. ncbi.nlm.nih.gov/pubmed/20059904>. Accessed: Mar. 29, 2019. doi: $10.3168 /$ jds.2009-2038

DIEZ-FRAILE, A. et al. L-selectin and $\beta 2$-integrin expression on circulating bovine polymorphonuclear leukocytes during endotoxin mastitis. Journal of Dairy Science, v.86, n.7, p.2334-2342, 2003. Available from: <https://www.sciencedirect.com/science/ article/pii/S0022030203738260>. Accessed: Mar. 29, 2019. doi: 10.3168/jds.S0022-0302(03)73826-0.

DONG, G. et al. Diet-induced bacterial immunogens in the gastrointestinal tract of dairy cows: impacts on immunity and metabolism. Acta veterinaria Scandinavica, v.53, p.48, 2011. Available from: <http:/www.ncbi.nlm.nih.gov/pubmed/21824438>. Accessed: Mar. 28, 2019. doi: 10.1186/1751-0147-53-48.

ENEMARK, J. M. The monitoring, prevention and treatment of sub-acute ruminal acidosis (SARA): a review. Veterinary Journal, v.176, n.1, p.32-43, 2008. Available from: <http://www.ncbi. nlm.nih.gov/pubmed/18343172>. Accessed: Mar. 29, 2019. doi: 10.1016/j.tvj1.2007.12.021.

FALEIROS, R. et al. Calprotectin in myeloid and epithelial cells of laminae from horses with black walnut extract-induced laminitis. Journal of Veterinary Internal Medicine, v.23, n.1, p.174-181, 2009. Available from: <https://www.ncbi.nlm.nih.gov/ pubmed/19175737>. Accessed: Mar. 29, 2019. doi: 10.1111/j.19391676.2008.0241.x.

FALEIROS, R. et al. Presence of mononuclear cells in normal and affected laminae from the black walnut extract model of laminitis. Equine Veterinary Journal, v.43, n.1, p.45-53, 2011. Available from: <https://www.ncbi.nlm.nih.gov/pubmed/21143633>. Accessed: Mar. 28, 2019. doi: 10.1111/j.2042-3306.2010.00121.x.

FEITOSA, F. L. F. Semiologia Veterinária: a Arte do Diagnóstico. São Paulo: Roca. 2008. 754p.

FERREIRA, P. Enfermidades podais em rebanho leiteiro confinado. 2003. 79f. Tese (Doutorado em Medicina Veterinária) - Escola de Veterinária, Universidade Federal de Minas, Belo Horizonte.

FOLNOZIC, I. et al. Influence of Body Condition on Serum Metabolic Indicators of Lipid Mobilization and Oxidative Stress in Dairy Cows During the Transition Period. Reproduction in Domestic Animals, v.50, n.6, p.910-7, 2015. Available from: <http:// www.ncbi.nlm.nih.gov/pubmed/26403271>. Accessed: Mar. 29, 2019. doi: 10.1111/rda.12608.

GERROS, T. C. et al. Alterations in clinical, hematological and metabolic variables in bovine neonatal endotoxemia. Canadian Journal of Veterinary Research, v.59, n.1, p.34-9, 1995. Available from: <http://www.ncbi.nlm.nih.gov/pubmed/7704840>. Accessed: Mar. 29, 2019.

GREENOUGH, P. R. Bovine laminitis and lameness: a hands on approach. Elsevier. 2007.

Ciência Rural, v.50, n.8, 2020. 
KOFLER, J. Patogenesis and treatment of toe lesions im cattle including nonhealing toe lesions. Veterinary Clinics: Food Animal Practice. v.33, p.301-328, 2017. Available from: $<$ https:// www.ncbi.nlm.nih.gov/pubmed/28579046>. Accessed: Mar. 29, 2019. doi: 10.1016/j.cvfa.2017.02.005.

LUNA, L. G. Manual of histologic staining methods of the Armed Forces Institute of Pathology. Nova Iorque: McGraw Hill Book Company. 1968. 224p.

MENDES, H. M. et al. Histopathology of dairy cows' hooves with signs of naturally acquired laminitis. Pesquisa Veterinaria Brasileira, v.33, n.5, p.613-619, 2013. Available from: $<\mathrm{http}$ //www.scielo.br/scielo.php?script $=\mathrm{sci}$ arttext\&pid=S0100736X2013000500011\&lng=en\&nrm=iso>. Accessed: Mar. 29, 2019. doi: 10.1590/S0100736 X2013000500011.

MILLAR, H. et al. An evaluation of the heat precipitation method for plasma fibrinogen estimation. Journal of clinical Pathology, v.24, n.9, p.827-830, 1971. Available from: <https://www.ncbi. nlm.nih.gov/pubmed/5003786>. Accessed: Mar. 29, 2019. doi: 10.1136/jcp.24.9.827.

NAGARAJA, T. G.; TITGEMEYER, E. C. Ruminal acidosis in beef cattle: The curent microbiological and nutritional outlook. Journal of Dairy Science, v.90, E17 - E38, 2007.

NICOLETTI, J. L. Manual de podologia bovina. Barueri: Manole. 2004. 130p.

NILSSON, S. A. Clinical, morphological, and experimental studies of laminitis in cattle. Acta Veterinaria Scandinavica, v.4, n.Suppl. 1. 1963. Available from: <https://www.semanticscholar. org/paper/Clinical\%2C-morphological\%2C-and-experimentalstudies-Nilsson/f8b75ebaeecd2ebf5376617aba343b268715ed0e>. Accessed: Mar. 28, 2019. doi: 10.1590/s0100-736x2013000500011.

NOCEK, J. E. Bovine acidosis: implications on laminitis. Journal of dairy science, v.80, n.5, p.1005-28, 1997. Available from: $<$ http://www.ncbi.nlm.nih.gov/pubmed/9178142>. Accessed: Mar. 28, 2019. doi: 10.3168/jds.S0022-0302(97)76026-0.

NRC. Nutrient Requirements of Beef Cattle. Washington, DC: Natl. Acad. Press. 1996.

PEÑAILILLO, A. et al. Haematological and blood biochemical changes induced by the administration of low doses of Escherichia coli lipopolysaccharide in rabbits. Archivos de Medicina Veterinaria, v.48, n.3, 2016. Available from: $<$ https://scielo.conicyt.cl/scielo.php?script=sci arttext\&pid $=$ S0301732X2016000300012\&lng=en\&nrm $=$ iso $>$. Accessed: Mar. 29, 2019. doi: 10.4067/S0301-732X2016000300012.

PERIASAMY, S. et al. Effects of Pasteurella multocida lipopolysaccharides on bovine leukocytes. Microbial Pathogenesis, v.119, p.225-232, 2018. Available from: <http:// www.ncbi.nlm.nih.gov/pubmed/29678740>. Accessed: Mar. 28, 2019. doi: 10.1016/j.micpath.2018.04.030.

QUINN, P. et al. Microbiologia Veterinária e Doenças Infecciosas. São Paulo: Artmed 2005.

SIQUEIRA, B. G.; A. SCHMIDT. Choque circulatório: definição, classificação, diagnóstico e tratamento. Medicina (Ribeirão Preto. Online), v.36, n.2/4, p.145-150, 2003. Available from: $<$ http://www.revistas.usp.br/rmrp/article/view/540>. Accessed: Mar. 29, 2019. doi: 10.11606/issn.2176-7262.v36i2/4p145-150.

SMITH, G. W. Supportive therapy of the toxic cow. The Veterinary clinics of North America Food animal practice, v.21, n.3, p.595-614, 2005. Available from: <http://www.ncbi. nlm.nih.gov/pubmed/16243625>. Accessed: Mar. 28, 2019. doi: 10.1016/j.cvfa.2005.07.005.

TARLTON, J. F. et al. Biomechanical and histopathological changes in the support structures of bovine hooves around the time of first calving. Veterinary Journal, v.163, n.2, p.196-204, 2002. Available from: <http://www.ncbi.nlm.nih.gov/pubmed/12093195>. Accessed: Mar. 29, 2019. doi: 10.1053/tvj1.2001.0651.

TAVARES, N. C.; et al. O impacto de dietas de alto valor energético sobre o ambiente ruminal e o tecido digital em bovinos confinados. Pesquisa Veterinária Brasileira, v.39, p.970-977, 2019. Available from: <https://www.scielo.br/scielo.php?pid=S0100736X2019001200970\&script $=$ sci_abstract\&tlng=pt $>$. Accessed: Mar. 29, 2019. doi: 10.1590/1678-5150-pvb-6230.

THOEFNER, M. B. et al. Histopathology of oligofructose-induced acute laminitis in heifers. Journal of Dairy Science, v.88, n.8, p.2774-82, 2005. Available from: <http://www.ncbi.nlm.nih.gov/ pubmed/16027191>. Accessed: Mar. 28, 2019. doi: 10.3168/jds. S0022-0302(05)72957-X

VISSER, M. B.; C. C. POLLITT. The timeline of lamellar basement membrane changes during equine laminitis development. Equine Veterinary Journal, v.43, n.4, p.471-477, 2011. Available from: $<$ http://www.ncbi.nlm.nih.gov/pubmed/21496071>. Accessed: Mar. 28, 2019. doi: 10.1111/j.2042-3306.2010.00292.x. 